\title{
Pre-dispersal SEed loss of Ramorinoa girolae (FABAceAe) in Ischigualasto Provincial Park (San Juan, Argentina)
}

\author{
SOFÍA PAPÚ1 ${ }^{1}$, SUSANA LAGOS SILNIK² and CLAUDIA M. CAMPOS ${ }^{2}$
}

\begin{abstract}
Summary: Ramorinoa girolae Speg. is a "vulnerable" tree endemic to Argentina. During the pre-dispersal stage, the seeds are predated by Anypsipyla univitella. The objectives of this study were to describe some reproductive parameters (size and number of fruits and seeds) of $R$. girolae, to quantify pre-dispersal seed loss by abortion and predation, and to test the effect on pre-dispersal seed predation of fruit production (per tree, of co-specific neighbors, and the sum of both), size of fruits, number of seeds per fruit, and number of predators per fruit. As seeds can be partially consumed by the predator, the viability of partially damaged seeds was assessed as well. At Ischigualasto Park, we sampled 17 adult trees from 3 stands spaced $4 \mathrm{~km}$ apart. For each focal tree, we quantified the number of co-specific neighbors and their fruits. We collected ten fruits from canopies and recorded their length and the number and states of seeds (intact, predated, and aborted). Generalized Linear Mixed Models were fitted to evaluate explanatory variables affecting the proportion of pre-dispersal predated seeds. $R$. girolae suffers great loss of seeds during the pre-dispersal stage, mainly by seed predation (58\% of seeds). The proportion of predated seeds was most important relative to the number of predators, the number of seeds per fruit, and the size of fruits. Fruits containing more predators, more seeds, and smaller fruits had higher proportions of predated seeds. Seed abortion would not represent an important factor of seed loss ( $6 \%$ of seeds).
\end{abstract}

Key words: Anypsipyla univitella, fruit production, fruit size, seed abortion, seeds per fruit, seed viability.

Resumen: Pérdida pre-dispersiva de semillas de Ramorinoa girolae Speg. (Fabaceae) en el Parque Provincial Ischigualasto (San Juan, Argentina). Ramorinoa girolae es una especie "vulnerable" endémica de Argentina, cuyas semillas son depredadas por Anypsipyla univitella durante la etapa pre-dispersiva. El objetivo de este estudio fue describir algunos parámetros reproductivos (tamaño y número de frutos y semillas) de $R$. girolae, cuantificar la pérdida de semillas por aborto y depredación durante la etapa predispersiva y evaluar el efecto que tienen factores como la producción de frutos (por árbol, de los vecinos co-específicos y la suma de ambos), tamaño del fruto, número de semillas por fruto y número de depredadores por fruto sobre la depredación pre-dispersiva. Además, se analizó la viabilidad de las semillas consumidas parcialmente. En el Parque Provincial Ischigualasto, se trabajó con 17 individuos adultos de tres subpoblaciones separadas $4 \mathrm{~km}$. Para cada árbol focal, se cuantificó el número de vecinos co-específicos y la producción de frutos. Se colectaron diez frutos de la copa de cada árbol focal y se midió su longitud y el número y estado de las semillas (intactas, depredadas y abortadas). Se construyeron Modelos Lineales Generalizados Mixtos para evaluar cuáles son las variables que mejor explican la proporción de semillas depredadas. $R$. girolae sufre una importante pérdida de semillas durante la etapa pre-dispersiva, principalmente debido a la depredación por A. univitella (58\%). La proporción de semillas depredadas se relaciona principalmente con el número de depredadores, el número de semillas por fruto y el tamaño del fruto. Las mayores proporciones de semillas depredadas se encontraron en frutos que contenían más depredadores, más semillas por fruto y frutos de menor tamaño. El aborto de semillas no representaría un importante factor de pérdida de semillas (6\%).

Palabras clave: Aborto de semillas, Anypsipyla univitella, número de semillas, producción de frutos, tamaño de frutos, viabilidad.

\footnotetext{
${ }^{1}$ Facultad de Ciencias Agrarias, Universidad Nacional de Cuyo

2 Instituto Argentino de Investigaciones de las Zonas Áridas, IADIZA- CONICET, Mendoza.

spapu@mendoza-conicet.gob.ar; slagos@mendoza-conicet.gob.ar; ccampos@mendoza-conicet.gob.ar
} 


\section{INTRODUCTION}

Ramorinoa girolae Speg. (Fabaceae), commonly named "chica", is a tree species endemic to central western Argentina that belongs to a monotypic genus in the Fabaceae family. Its limited geographical distribution includes the mountain slopes of San Juan, San Luis and La Rioja provinces (Fig. 1 A; Hunziker \& Coccucci, 1961; Beorchia Nigris, 2001; Demaio et al., 2002). $R$. girolae is a slow-growing, leafless tree, with green stems and up to $10 \mathrm{~m}$ high (Hadad et al., 2014). It has high wood density (1.265 kg/dm³ ; Kiesling, 1994) and low resistance to fire (Demaio et al., 2002). The wood is used to make crafts, tools, and parts of musical instruments (Kiesling, 1994). Edible seeds of $R$. girolae are usually consumed by the inhabitants of rural settlements close to "chica" forests ("chicales"), and represent a useful food for human nutrition as a rich source of antioxidant compounds (Luna et al., 2013).

$R$. girolae fruits are hard, indehiscent, and multi- seeded legumes. Pre-dispersal seed predation is related to only one lepidoptera species, Anypsipyla univitella Dyar. (Phycitinae, Pyralidae, Lepidoptera; Papú, 2014), described in Panama (Neunzig, 2003) and recorded across Central and South America. This species eats seeds of Fabaceae, particularly of Prosopis species (Neunzig, 2003; Mc Kay \& Gandolfo, 2007). A. univitella was found to be associated with Goniozus sp. (Bethylidae, Chrysidoidea, Hymenoptera; Papú, 2014), a parasitoid wasp that parasitizes coleoptera and lepidoptera larvae used in control populations of agricultural pests (Stokkebo \& Hardy, 2000; Goubault et al., 2008; Bentley et al., 2009; Lizé et al., 2012). When fruits ripe, they disperse first by gravity and remain under the tree canopy until removed by Octomys mimax, a small rodent who gathers the harvested fruits in fairly large quantities (Campos, 2012). As in other Fabaceae species, seed germination requires scarification in order to break dormancy (Meglioli et al., 2012).

The first population study, carried out at Pie

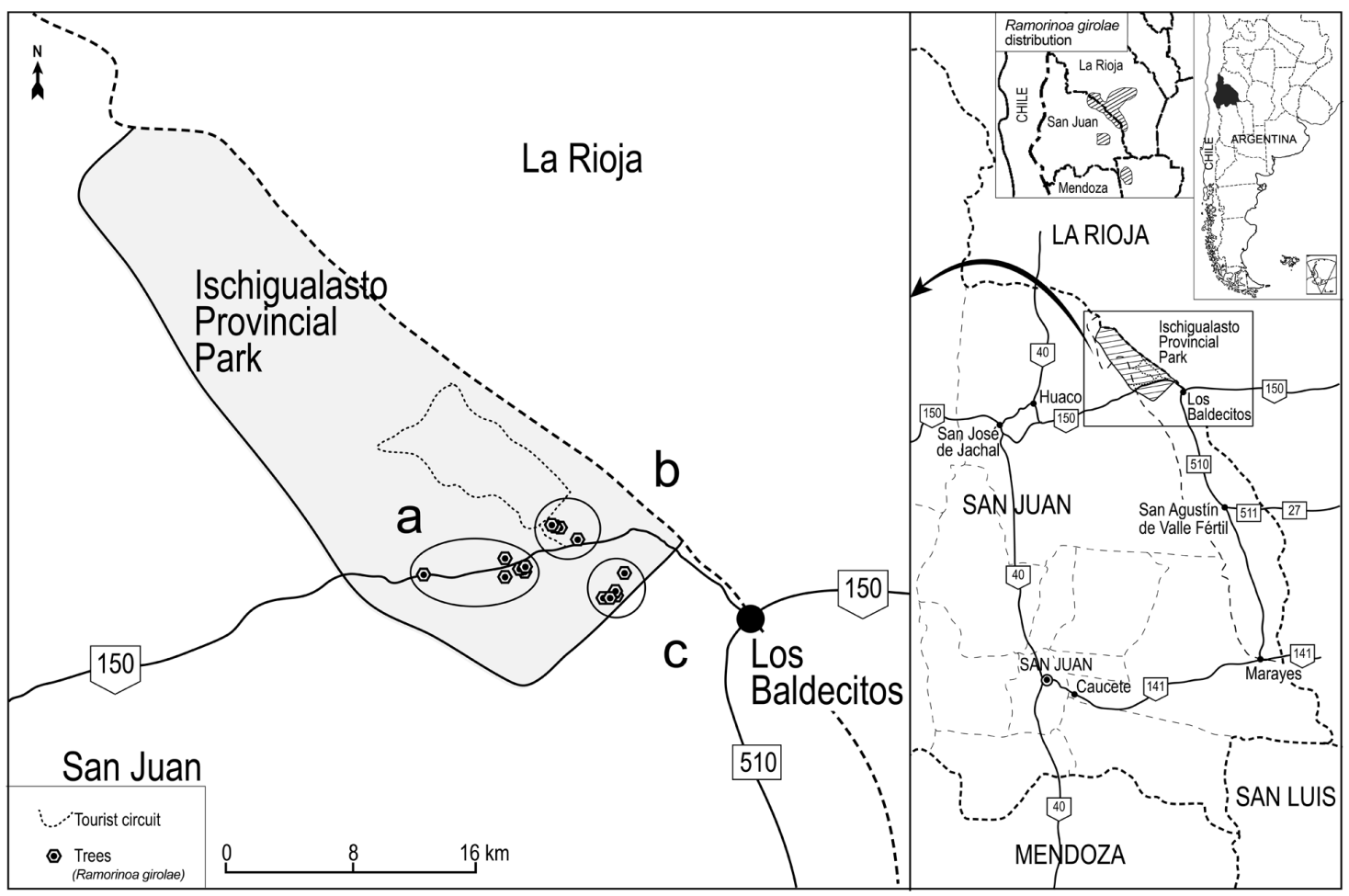

Fig. 1. Distribution of Ramorinoa girolae, which includes the mountain slopes of San Juan, San Luis and La Rioja provinces. The three stands of R. girolae selected: Mina de cuarzo (c), Morado (b) and Tramo (a). 


\section{S. Papú et al. - Pre-dispersal seed loss of Ramorinoa girolae in San Juan}

de Palo (San Juan province), showed lack of $R$. girolae regeneration in the last decades (Hadad et al., 2014). These results agree with observations at Ischigualasto Provincial Park, where occurrence of seedlings and saplings is scarce (Campos, per. obs.). $R$. girolae was categorized as "vulnerable" due to its restricted distribution, low growth, and low resistance to fire (Demaio et al., 2002). Currently, it is being assessed for inclusion in the "endangered" category by the International Union for Conservation of Nature (IUCN; Hadad et al., 2014).

In view of the importance of sexual reproduction based on genetic results (Ortiz, 2014), and of the low regeneration of $R$. girolae (Hadad et al., 2014), it becomes important to study the processes related to seed loss. Whereas post-dispersal seed removal could be attributed mainly to $O$. mimax and to human use, pre-dispersal seed loss could involve factors that are still unknown.

In plants, the main factors of pre-dispersal seed loss are abortion, which limits considerably the amount of seeds produced (Stephenson, 1981; Sutherland, 1986), and seed predation by arthropods, which may cause the destruction of a great proportion of the seeds produced limiting the number of seeds to be dispersed (Janzen, 1971; Louda, 1983). Pre-dispersal seed predation takes place while seeds are still on the mother plant, mainly involving small and specialized arthropods of the orders Coleoptera, Diptera, Hymenoptera and Lepidoptera (Hulme \& Benkman, 2002). There is evidence from many plant species that pre-dispersal seed predators damage a considerable and variable proportion of seeds (Crawley, 1992; Kolb et al., 2007). This animal-plant interaction can involve distance-dependent and density-dependent processes (Janzen, 1970), thus distance among plants and density of fruits and seeds could affect the intensity of seed predation (Ehrlén, 1996).

Plants have evolved both resistance and satiation strategies to reduce the fitness costs of seed predation. Resistance mechanisms preclude consumption and include physical barriers, like hard seed coats, or chemical defenses (Harper et al., 1970; Janzen, 1971; Hulme \& Benkman, 2002), whereas predator satiation can be achieved at population level by mast seeding (Kelly, 1994; Kelly \& Sork, 2002), and at individual level by large seed crops (Crawley, 1992) and large-sized seeds (Bonal et al., 2007).
Number of seeds per fruit is an important factor in determining predation (Janzen, 1969). In species of Scheelea, multi-seeded fruits have a greater probability of escaping bruchid predation than fruits with one seed (Bradford \& Smith, 1977). Seeds in fruits with only one large seed contain more energy than smaller seeds in multi-seeded fruits, where seeds are encapsulated and protected from bruchid attack (Bradford \& Smith, 1977). However, it was found that fruits of Acacia aroma with a greater number of seeds were preferred by female bruchids who thus minimize both the energetic cost of searching for seeds and predation risk (Aizen, 1991).

The effects of pre-dispersal seed predation by arthropods on germination and recruitment of legumes can be unpredictable (Southgate, 1979). In some cases, the arthropod acts as a seed predator because larvae effectively kill the embryo or remove so much endosperm that the seed cannot germinate (El Atta, 1993; Camargo-Ricalde et al., 2004; Tomaz et al., 2007). In other cases, despite the detrimental effects of seed predation, some proportion of infested seeds will germinate (Halevy, 1974; Hoffman et al., 1989; Mack, 1998; Velez, 2013), and even arthropod damage has been considered useful to improve the scarification required for successful seed germination (Takakura, 2002; Fox et al., 2012).

The objectives of this study were to describe some reproductive parameters (size and number of fruits and seeds) of $R$. girolae, to quantify predispersal seed loss by abortion and predation by A. univitella, and to test the effect on pre-dispersal seed predation of fruit production (of focal trees and focal trees plus co-specific neighbors), size of fruits, number of seeds per fruit, and number of predators per fruit. As seeds can be partially consumed by the predator, the viability of partially damaged seeds was assessed as well.

\section{Materials and Methods}

\section{Study area}

The study was conducted in Ischigualasto Provincial Park, San Juan province, Argentina

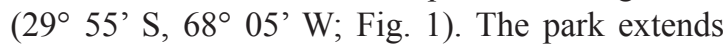
over 62,916 ha at a mean altitude of $1300 \mathrm{~m}$ asl, and is mainly included in the northern Monte 
desert (Burkart et al., 1999). The climate is arid, with an average annual precipitation of $183 \mathrm{~mm}$. It is characterized by humid summers (average November-March precipitation: $100 \mathrm{~mm}$ ) and dry winters (average April-October precipitation: 8 $\mathrm{mm}$ ). Mean temperature in summer is $24.3^{\circ} \mathrm{C}$, with an absolute maximum of $45^{\circ} \mathrm{C}$. Mean temperature in winter is $8.5^{\circ} \mathrm{C}$, with an absolute minimum of $-10^{\circ} \mathrm{C}$ (De Fina et al., 1962). The landscape is characterized by open scrublands dominated by shrubs, cacti, and bromeliads (Márquez et al., 2005; Acebes et al., 2010). Open forests of Prosopis flexuosa, P. chilensis, Bulnesia retama and $R$. girolae occur at the park. These forests are considered of high conservation value by provincial and national laws (Laws 26331 and 8174).

\section{Study design}

In January 2013, we selected three stands of $R$. girolae separated by approximately $4 \mathrm{~km}$ at three sites: Tramo, Morado and Mina de cuarzo (Fig. $1 \mathrm{a}, \mathrm{b}$ and c respectively) in the "chical" community (Acebes et al., 2010). From each stand, we randomly chose adult trees with ripe fruits that were at least $100 \mathrm{~m}$ apart (Tramo: 6 focal trees,
Morado: 6, Mina de cuarzo: 5). In order to describe density of trees and fruit production, we recorded the number of co-specific neighbors and their fruits in a $20 \mathrm{~m}$ radius around every focal tree $(\mathrm{N}=17)$. We randomly collected ten fruits from the canopy of every focal tree (Fig. 2 A). In the laboratory, as an estimator of fruit size, we measured the length of every fruit with a caliper. Each fruit was kept for 6 months in closed jars, in order to let A. univitella complete its life cycle. Fruits were checked every week and emerging adults were removed to prevent matting and reinfection of fruits. After incubation period, we opened the fruits and recorded the number of seeds per fruit, the volume of every intact seed (length, width, and thickness), and the number of larvae, pupae, and adults of $A$. univitella. The state of seeds was classified as intact (without signs of damage), predated, and aborted (small and malformed seeds; Fig. 2 a, b, c).

Seed viability was assessed indirectly by the 2, 3, 5-triphenyl-tetrazolium chloride test (PiliSevilla, 1987), which detects seed viability by staining the embryo tissue pink/red. In the case of predated seeds, the treatment could only be applied to partially damaged seeds.

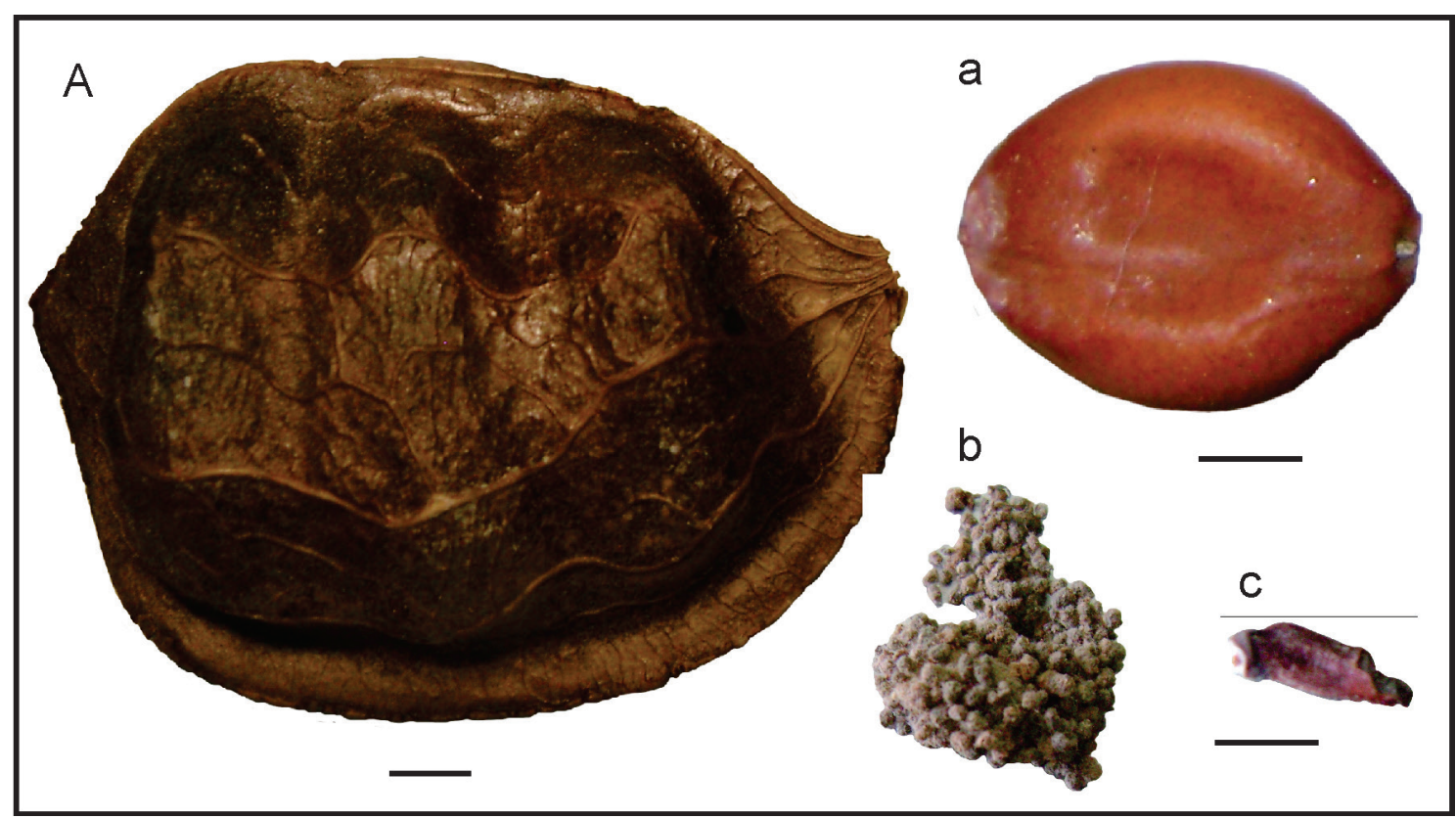

Fig. 2. Fruit of Ramorinoa girolae (A). State of seeds: intact (a), predated by Anypsipyla univitella (b), and aborted (c) (Scale: $5 \mathrm{~mm}$ ). 


\section{S. Papú et al. - Pre-dispersal seed loss of Ramorinoa girolae in San Juan}

\section{Data analysis}

Generalized linear mixed models (GLMMs; McCullagh \& Nelder, 1989) were parametrized in order to examine whether fruit production (per tree, of co-specific neighbors, and the sum of both), size of fruits, number of seeds per fruit, and number of predators per fruit (explanatory variables) affect the proportion of predated seeds (response variable), "Trees within sites" was considered a nested random factor. We used GLMMs with a binomial error structure because the response data were strictly bounded proportions, the variance was not constant and the errors were non-normal (Crawley, 2007). To identify collinearity among explanatory variables, we used Spearman rank correlation in order to remove correlated variables (Zar, 1999). We excluded variables when the coefficient $r$ was $>0.8$. In order to avoid underestimating pre-dispersal seed predation, this magnitude was expressed as the proportion of predated seeds relative to the number of seeds in the fruit excluding aborted seeds (Kolb et al., 2007).

We used the information-theoretic approach described by Burnham and Anderson (2002) to select the best model, based on the second-order Akaike Information Criterion corrected for small sample size (AICc). Models were compared with $\triangle \mathrm{AICc}$, which is the difference between the lowest AICc value (i.e., the best of suitable models) and AICc for all the other models.

We considered the Akaike weight of every model $\left(\mathrm{w}_{\mathrm{i}}\right)$ in order to determine the relative likelihood that the specific model is the best of the set of all models. The $\mathrm{w}_{\mathrm{i}}$ for a model is just exp $(-0.5 \times \triangle \mathrm{AICc}$ score for that model) divided by the sum of these values across all models. The support for predictor variables was estimated by summing $\mathrm{w}_{\mathrm{i}}$ across all models that contained the parameter being considered (parameter likelihood; Burnham \& Anderson, 2002). Parameter estimates were calculated using model-averaged parameter estimates based on $\mathrm{w}_{\mathrm{i}}$ for all candidate models. To supplement parameter-likelihood evidence of important effects, $97.2 \%$ confidence interval limits $(\mathrm{CL})$ of parameter estimates were determined. All statistical analyses were conducted using R environment (2014).

\section{REsULts}

Tree density at the study sites was $27.67 \mathrm{ind} / \mathrm{ha}$
$( \pm \mathrm{SE}=0.62)$, and fruit production per tree was on average $179.73( \pm 59.83$; range $=0-3000 ; \mathrm{N}=59$ trees). Mean fruit size was $44.20 \mathrm{~mm}( \pm 3.52 ; \mathrm{N}=170$ fruits from 17 focal trees; Fig. 3). The fruits contained from 1 to 5 seeds $($ mean $=2.78 \pm 0.08 ;$ median $=3$ ) with a mean volume of $725.12 \mathrm{~mm}^{3}( \pm 19.45 ; \mathrm{N}=171$ intact seeds).

Almost $48 \%$ of the examined fruits had all their seeds predated by $A$. univitella, whereas $30 \%$ of the fruits had been neither predated nor aborted. The fruits with some predated seeds had one or two predators inside them. Twenty percent of the fruits with predated seeds contained two individuals, and $80 \%$ only one of them.

Taking into account all analyzed seeds $(\mathrm{N}=470)$, $36.40 \%$ were intact seeds, $57.90 \%$ were predated seeds, and 5.75\% were aborted seeds. Figure 3 shows the proportion of viable seeds considering each state.

Because the explanatory variable fruit production per tree plus co-specific neighbors was correlated to fruit production per tree $(r=0.90 ; \mathrm{S}=83634.54$; $P<0.00001)$, it was not considered in modelling. This was the only collinearity found among explanatory variables. There were several models accounting for the effect of explanatory variables on the proportion of seeds predated by $A$. univitella. The best models $\left(\Delta_{\mathrm{i}}<2\right)$ mainly included number of predators per fruit, number of seeds per fruit, and size of fruits (Table 1). The confidence intervals for these explanatory variables excluded zero and also had the highest parameter likelihood (Table 2). The number of predators per fruit and the number of seeds per fruit were directly related to the response variable whereas the size of fruits was inversely related to it (Table 2).

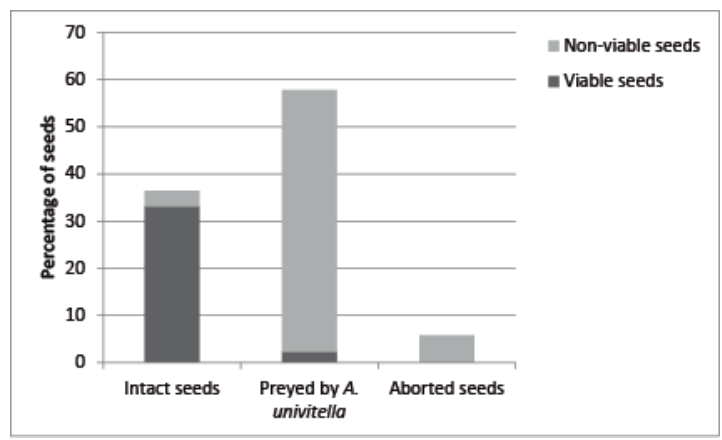

Fig. 3. Percentages of viable and non-viable seeds considering each state (intact, predated by Anypsipyla univitella, and aborted). 
Table 1. Summary of model-selection results for models explaining the proportion of seeds predated by Anypsipyla univitella in relation to fruit production per tree, fruit production of co-specific neighbors, size of fruits, number of seeds per fruit, and number of predators per fruit. $k$ is the number of estimated parameters. Models with $\Delta_{i}<2$, univariate models and null model are shown and listed in decreasing order of importance.

\begin{tabular}{|c|c|c|c|c|}
\hline Model & k & $\mathrm{AlCc}$ & $\Delta \mathrm{i}$ & wi \\
\hline Number of $A$. univitella per fruit + Size of fruits + Number of seeds per fruit & 6 & 251.13 & 0.00 & 0.39 \\
\hline $\begin{array}{l}\text { Number of } A \text {. univitella per fruit }+ \text { Size of fruits+Number of seeds per } \\
\text { fruit+Fruit production per tree }\end{array}$ & 7 & 251.88 & 0.75 & 0.27 \\
\hline $\begin{array}{l}\text { Number of } A \text {. univitella per fruit }+ \text { Size of fruits+Number of seeds per } \\
\text { fruit+Fruit production of coespecific neighbors }\end{array}$ & 7 & 253.06 & 1.93 & 0.15 \\
\hline $\begin{array}{l}\text { Number of } A \text {. univitella per fruit }+ \text { Size of fruits+Number of seeds per } \\
\text { fruit+Fruit production of coespecific neighbors+Fruit production per tree }\end{array}$ & 8 & 253.33 & 2.20 & 0.13 \\
\hline Number of $A$. univitella per fruit & 4 & 315.76 & 64.63 & 0.00 \\
\hline Size of fruits & 4 & 363.78 & 112.66 & 0.00 \\
\hline Fruit production per tree & 4 & 394.12 & 142.99 & 0.00 \\
\hline Number of seeds per fruit & 4 & 397.77 & 146.64 & 0.00 \\
\hline Null & 3 & 400.39 & 149.26 & 0.00 \\
\hline Fruit production of coespecific neighbors & 4 & 402.29 & 151.16 & 0.00 \\
\hline
\end{tabular}

Table 2. Parameter likelihoods, estimates ( \pm SE) and $97.5 \%$ confidence interval limits $(C L)$ for explanatory variables describing proportion of seeds predated by Anypsipyla univitella in relation to fruit production per tree, fruit production of co-specific neighbors, size of fruits, number of seeds per fruit, and number of predators per fruit. Explanatory variables with $\mathrm{CL}$ excluding zero are in italics.

\begin{tabular}{|c|c|c|c|c|}
\hline \multirow[t]{2}{*}{ Explanatory variable } & \multirow[t]{2}{*}{ Parameter likelihood } & \multirow[t]{2}{*}{ Parameter estimate \pm SE } & \multicolumn{2}{|c|}{$\mathrm{CL}$} \\
\hline & & & Lower & Upper \\
\hline Intercept & & $4.676 \pm 0.879$ & 2.953 & 6.399 \\
\hline $\begin{array}{l}\text { Number of } A \text {. univitella per } \\
\text { fruit }\end{array}$ & 1 & $2.689 \pm 0.325$ & 2.051 & 3.327 \\
\hline Number of seeds per fruit & 1 & $0.569 \pm 0.209$ & 0.160 & 0.978 \\
\hline Size of fruits & 0.94 & $-0.160 \pm 0.024$ & -0.207 & 0 \\
\hline Fruit production per tree & 0.43 & $-0.001 \pm 0.001$ & -0.002 & 0.001 \\
\hline $\begin{array}{l}\text { Fruit production of coespecific } \\
\text { neighbours }\end{array}$ & 0.30 & $0.000 \pm 0.000$ & -0.001 & 0.001 \\
\hline
\end{tabular}

\section{Discussion}

The present study has made the first estimation of fruit production and of pre-dispersal seed loss in $R$. girolae. The third part of produced seeds passed through the pre-dispersal stage as intact seeds, with a viability of nearly $100 \%$, whereas almost $60 \%$ of seeds were lost to predation by A. univitella, and $6 \%$ were lost by abortion. These results corroborate that pre-dispersal seed predation is the major cause of seed loss.
Compared to Prosopis spp., R. girolae showed a higher percentage of predated seeds (P. flexuosa, $P$. chilensis, and $P$. ferox showed respectively $18 \%$, $14 \%$ and $15 \%$ of seeds predated by arthropods; Ortega-Baes et al., 2001; Velez, 2013). In the case of Prosopis species, seed mortality due to reinfection can be very high if fruits remain under the canopy when not removed by disperser animals (Ortega Baez et al., 2001), such as native and exotic mammals (mara, fox, guanaco, quirquincho, small rodents, cow, horse, donkey, European hare, etc.; 


\section{S. Papú et al. - Pre-dispersal seed loss of Ramorinoa girolae in San Juan}

Campos \& Ojeda, 1997; Campos et al., 2007, 2008, 2011; Giannoni et al., 2013). It is likely that the hard fruit of $R$. girolae acts as seed protector against reinfection under the canopy. The only animal that removes, stores, and is able to open fruits is the "viscacha rat" O. mimax, who eats the seeds (Campos, 2012).

In some cases, seed viability and germination appear to be little affected by arthropod predation, and seeds with as much as half of their cotyledonary reserves removed germinate as well as intact seeds (Dalling et al., 1997). A low percentage of $R$. girolae seeds predated by $A$. univitella retained their viability, but the quality of germination and seedling growth is still unknown. In $P$. flexuosa predation decreased both germination rate and the growth and survival of seedlings during the first year (Velez, 2013).

The proportion of seeds lost to pre-dispersal predation by $A$. univitella was related to several factors, the most important being the number of predators per fruit, the number of seeds per fruit, and the size of fruits. Seed can be predated by one or two individuals, who can move among seeds drilling the septa that separate them. When fruits were attacked by two individuals, in 16 of 17 cases they predated on all of the seeds.

The fruits with higher proportions of predated seeds were those containing more seeds. Our results are consistent with findings by Aizen (1991) regarding Acacia aroma seeds predated by the bruchid Pseudopachymerina grata, with the only difference that $A$. univitella is able to predate on more than one seed per fruit. Also Stator limbatus, predating on Cercidium floridum seeds, oviposits in proportion to the abundance of resources in the fruits and larvae generally consume all the seeds, giving seeds from one-seeded fruits a higher likelihood of survival (Mitchell, 1977).

The fruits with higher proportions of predated seeds were the smaller ones. It might be possible that the healthiest trees produce large-sized and resistant fruits, reducing predation pressure. Also the dynamics of predator populations could affect their preference for fruits. For instance, Morandini and de Viana (2009) found that the preference of bruchids for different sizes of Enterolobium contortisiliquum fruits depended on intensity of competition among co-specific predators.

Regarding seed abortion, $6 \%$ of $R$. girolae seeds were aborted. This percentage falls within the range of number of aborted seeds in Prosopis species $(1-15 \%$ of the total number of seeds; $P$. alpataco, $P$. chilensis, $P$. flexuosa, and $P$. denudans in increasing order), and it is lower than in other leguminous species, in which seed abortion ranges from $40 \%$ to $85 \%$ (Bawa \& Webb, 1984). Even though it was not quantified, during this study, we also observed the loss of unripe fruits of $R$. girolae. It has been proposed that when reduction in plant fitness is high, selection would favor plant traits that reduce damage, for instance producing excess young fruits, which allows for subsequent abortion of attacked fruits (Östergard et al., 2007). This potential strategy of $R$. girolae would deserve a specific study.

Finally, as a descriptive result, the density of $R$. girolae (28 ind/ha) found in this study was similar to that obtained for the whole Park (33.85 ind/ha) according to studies of plant species distribution (Campos et al., not published data), although it was lower than density at Sierra de Pie de Palo (San Juan) where $117 \mathrm{ind} /$ ha were recorded (Hadad et al., 2014).

In conclusion, added to its restricted geographical distribution, slow growth, and poor fire resistance, $R$. girolae suffers a great loss of seeds during the pre-dispersal stage. Afterwards, seeds could be consumed by $O$. mimax or used by people, thus decreasing the likelihood of seed germination and seedling establishment. In view of the foregoing, it is necessary to continue to study the species' biology in order to identify key ecological factors for its in-situ conservation.

\section{ACKNOWLEDgeMENTS}

This research was supported by Presidencia de la Nación through the project "La chica, el retamo y el algarrobo: especies paraguas para la conservación del Bosque Nativo del Parque Provincial Ischigualasto. Interacciones biológicas, efectos de actividades humanas y su mitigación" (Responsible Technician: Stella M. Giannoni). We thank the staff of Ischigualasto Provincial Park and the Museum of the National University of San Juan for providing all the necessary facilities during fieldwork. This study is part of a graduate thesis of the first author at the National University of Cuyo, Argentina. 
We acknowledge and are grateful for the help received from all the members of INTERBIODES (Interacciones biológicas del desierto), particularly from S. Giannoni. The authors are CONICET (Consejo Nacional de Investigaciones científicas y Técnicas) researchers and fellows. Nélida Horak assisted us with language editing.

\section{REFERENCES}

ACEBES, P., J. TRABA, B. PECO, M. L. REUS, S. M. GIANNONI \& J. E. MALO. 2010. Abiotic gradients drive floristic composition and structure of plant communities in the Monte Desert. Rev. Chil. Hist. Nat. 83: 395-407.

AIZEN M. A. 1991. Predación de semillas de Acacia aroma por el brúchido Pseudopachymerina grata en función de la posición de las semillas y el número de semillas por vaina. Austral Ecol. 1: 17-23.

BAWA, K. S. \& C. J. WEBB. 1984. Flower, Fruit and Seed Abortion in Tropical Forest Trees: Implications for the Evolution of Paternal and Maternal Reproductive Patterns. Am. J. Bot. 71: 736-751.

BENTLEY, T., T. T. HULL, I. C. HARDY \& M. GOUBAULT. 2009. The elusive paradox: ownerintruder roles, strategies, and outcomes in parasitoid contests. Behav. Ecol. 20: 296-304.

BEORCHIA NIGRIS, A. 2001. Los Chicales de Pie de Palo. San Juan Tierra de Huarpes 2: 123-132.

BONAL, R., A. MUÑOZ \& M. DÍAZ. 2007. Satiation of predispersal seed predators: the importance of considering both plant and seed levels. Evol. Ecol. 21: 367-380.

BRADFORD, D. F. \& C. C. SMITH. 1977. Seed predation and seed number in Scheelea palm fruits. Ecology 58: 667-673.

BURKART, R., N. O. BARBARO, R. O. SÁNCHEZ \& D. A. GÓMEZ. 1999. Ecoregiones de la Argentina. Administración de Parques Nacionales, Buenos Aires.

BURNHAM, K. P. \& D. R. ANDERSON. 2002. Model selection and multimodel inference: a practical information-theoretic approach. Springer, New York.

CAMARGO-RICALDE, S. L., S. S. DHILLION \& V. GARCÍA-GARCÍA. 2004. Phenology, and seed production and germination of seven endemic Mimosa species (Fabaceae: Mimosoideae) of the Tehuacan-Cuicatlan Valley, Mexico. J. Arid Environ. 58: 423-437.

CAMPOS, C. \& R. OJEDA. 1997. Dispersal and germination of Prosopis flexuosa (Fabaceae) seeds by desert mammals in Argentina. J. Arid Environ. 35: 707-714.
CAMPOS, C. M., S. M. GIANNONI, P. TARABORELLI \& C. BORGHI. 2007. Removal of mesquite seeds by small rodents in the Monte desert, Argentina. J. Arid Environ. 69: 228-236.

CAMPOS, C. M., B. PECO, V. E. CAMPOS, J. E. MALO, S. M. GIANNONI \& F. SUÁREZ. 2008. Endozoochory by native and exotic herbivores in dry areas: consequences for germination and survival of Prosopis seeds. Seed Sci. Res. 18: 91-100.

CAMPOS, C. M., V. CAMPOS, A. MONGEAUD, C. BORGHI, C. DE LOS RÍOS \& S. M. GIANNONI. 2011. Relationships between Prosopis flexuosa (Fabaceae) and cattle in the Monte desert: seeds, seedlings and saplings on cattle-use site classes. Rev. Chil. Hist. Nat. 84: 289-299.

CAMPOS, V. E. 2012. Biología de Octomys mimax (Rodentia: Octodontidae): selección de hábitat y conservación en el Monte árido de San Juan. Doctoral Thesis. National University of Córdoba, Argentina.

CRAWLEY, M. J. 1992. Seed predators and plant population dynamics. In: FENNER, M. (ed.), Seeds: the ecology of regeneration in plant communities, $\mathrm{pp}$. 157-191. CAB International, Wallingford, UK.

CRAWLEY, M. J. 2007. The R Book. John Wiley and Sons, Ltd, Chichester, UK.

DALLING, J. W., K. E. HARMS \& R. AIZPRÚA. 1997. Seed damage tolerance and seedling resprout ability of Prioria copaifera ('El Cativo'). J. Trop. Ecol. 13: 617-621.

DE FINA, A. L., F. GIANNETTO \& L. J. SABELLA. 1962. Difusión geográfica de cultivos, índices en la provincia de San Juan y sus causas. Publicación $\mathrm{N}^{\circ}$ 80. Instituto de Suelos y Agrotecnia e INTA, Buenos Aires.

DEMAIO, P., U. O. KARLIN \& M. MEDINA M. 2002. Árboles nativos del centro de Argentina. L.O.L.A. (Literature of Latin America), Buenos Aires.

EHRLÉN, J. 1996. Spatiotemporal variation in predispersal seed predation intensity. Oecologia 108: 708-713.

EL ATTA, H. A. 1993. The effect of Caryedon serratus Olivier (Col., Bruchidae) on viability and germination of seeds of Acacia nilotica (L. Will). in the Sudan. For. Ecol. Manage. 57: 169-177.

FOX, C. W., W. G. WALLIN, M. L. BUSH, M. E. CZESAK \& F. J. MESSINA. 2012. Effects of seed beetles on the performance of desert legumes depend on host species, plant stage, and beetle density. $J$. Arid Environ. 80: 10-16.

GIANNONI, S. M., V. E. CAMPOS, N. ANDINO, M. RAMOS-CASTILLA, A. OROFINO, C. E. BORGHI, C. DE LOS RÍOS \& C. M. CAMPOS. 2013. Hoarding patterns of sigmodontine rodent species in the Central Monte desert (Argentina). Austral Ecol. 38: 485-492. 


\section{S. Papú et al. - Pre-dispersal seed loss of Ramorinoa girolae in San Juan}

GOUBAULT, M., T. P. BATCHELOR, R. ROMANI, R. S. T. LINFORTH, M. FRITZSCHE, W. FRANCKE \& I. C. W HARDY. 2008. Volatile chemical release by bethylid wasps: identity, phylogeny, anatomy and behaviour. Biol. J. Linn. Soc. 94: 837-852.

HADAD, M., M. ALMIRÓN \& J. SCAGLIA. 2014. Estructura de un bosque de Ramorinoa girolae (fabaceae), en la Sierra de Pie de Palo, San Juan (Argentina). Bol. Soc. Argent. Bot. 49: 283-292.

HALEVY, G. 1974. Effects of gazelle and seed beetles (Bruchidae) on germination and establishment of Acacia species. Israeli J. Bot. 23: 120-126.

HARPER, J. L., P. H. LOVELL \& K. G. MOORE. 1970. The shapes and sizes of seeds. Annu. Rev. Ecol. Syst. 1: 327-356.

HOFFMAN, M. T., R. M. COWLING, C. DOUIE \& S. M. PIERCE. 1989. Seed predation and germination of Acacia erioloba in the Kuiseb river valley, Namib desert. S. Afr. J. Bot. 55: 103-106.

HULME, P. E. \& C. W. BENKMAN. 2002. Granivory. In: HERRERA, C.CM. \& O. PELLMYR (eds.), Plantanimal interactions: an evolutionary approach, pp. 132-154. Blackwell, Oxford.

HUNZIKER, A. T. \& A. E. COCUCCI. 1961. Noticia sobre nuevas colecciones de Stenodrepanum bergii Harms. y Ramorinoa girolae Speg. (Leguminosae). Kurtziana 1: 307-308.

JANZEN, D. H. 1969. Seed-eaters versus seed size, number, toxicity and dispersal. Evolution 23: 1-27.

JANZEN, D. H. 1970. Herbivores and the number of tree species in tropical forests. Am. Nat. 104: 501-528.

JANZEN, D. H. 1971. Seed predation by animals. Annu. Rev. Ecol. Syst. 2: 465-492.

KELLY, D. 1994. The evolutionary ecology of mast seeding. Trends Ecol. Evol. 9: 465-470.

KELLY, D. \& V. L. SORK. 2002. Mast seeding in perennial plants: why, how, where? Annu. Rev. Ecol. Syst. 33: 427-447.

KIESLING, R. 1994. Flora de San Juan: Pteridophyta, Gymnosperma, multiple-leaf dicotyledons (Salicacea and Leguminosae). Volume I. Vázquez Mazzini Editores, Argentina.

KOLB, A., J. EHRLÉN \& O. ERIKSSON. 2007. Ecological and evolutionary consequences of spatial and temporal variation in pre-dispersal seed predation. Perspect. Plant Ecol. Evol. Syst. 9: 79100.

LIZÉ, A., S. K. KHIDR \& I. C. W. HARDY. 2012. Two components of kin recognition influence parasitoid aggression in resource competition. Anim. Behav. 83: 793-799.

LOUDA, S. M. 1983. Seed predation and seedling mortality in the recruitment of a shrub, Haplopappus venetus (Asteraceae), along a climatic gradient. Ecology 64: 522-521.
LUNA, L. C., N. B. PIGNI, L. TORREAS-CLAVERIA, M. V. MONFERRAN, D. MAESTRI, D. A. WUNDERLIN, G. E. FERESIN, J. BASTIDA \& A. TAPIA. 2013. Ramorinoa girolae Speg (Fabaceae) seeds, an Argentinean traditional indigenous food: nutrient composition and antioxidant activity. $J$. Food Compos. Anal. 31: 120-128.

MACK, A. L. 1998. An advantage of large seed size: tolerating rather than succumbing to seed predators. Biotropica 30: 604-608.

MÁRQUEZ, J., M. E. CARRETERO, A. DALMASSO, G. PASTRÁM \& G. ORTIZ. 2005. Las Áreas Protegidas de la Provincia de San Juan II. La vegetación del Parque Provincial Inschigualasto. Multiequina 14: 1-27.

MC KAY, F. \& D. GANDOLFO. 2007. Phytophagous insects associated with the reproductive structures of mesquite (Prosopis spp.) in Argentina and their potential as biocontrol agents in South Africa. African Entomol. 15: 121-131.

MCCULLAGH, P. \& J. A. NELDER. 1989. Generalized linear models. 2nd ed. Monograph on statistics and applied probability 37. Chapman \& Hall, New York.

MEGLIOLI, C., J. A SCAGLIA, M. HADAD \& G. DÍAZ BISUTTI. 2012. Evaluación del poder germinativo de Ramorinoa girolae Speg. (Fabaceae) bajo diferentes tratamientos pregerminativos. Análisis de Semillas 6: 62-65.

MITCHELL, R. 1977. Bruchid bettles and seed packaging by Palo Verde. Ecology 58: 644-651.

MORANDINI, M., \& M. DE VIANA. 2009. Depredación pre-dispersiva de semillas en tres poblaciones del árbol Enterolobium contortisiliquum (Fabaceae). Rev. Biol. Trop. 57: 781-788.

NEUNZIG, H. H. 2003. New Phycitine records for the Dominican Republic and description of a new species of Nefundella (Lepidoptera: Pyralidae: Phycitinae). Trop. Lep. 11: 7-12.

ORTEGA-BAES, P., M. DE VIANA \& M. SARAVIA. 2001. The fate of Prosopis ferox seeds from unremoved pods at National Park Los Cardones. $J$. Arid Environ. 48: 185-190.

ORTIZ, N. R. 2014. Estudio de la estructura genética espacial de Ramorinoa girolae (chica), una especie endémica de gran vulnerabilidad. Graduate Thesis. National University of Cuyo, Mendoza, Argentina.

ÖSTERGARD H., P. A. HAMBÄCK \& J. EHRLÉN. 2007. Pre-dispersal seed predation: The role of fruit abortion and selective oviposition. Ecology 88: 2959-2965.

PAPÚ, S. 2014. Caracterización general y depredación predispersiva de chica (Ramorinoa girolae) en el Parque Provincial Ischigualasto (San Juan, Argentina). Graduate Thesis. National University of Cuyo, Argentina. 
Bol. Soc. Argent. Bot. 50 (4) 2015

PILI-SEVILLA, E. 1987. Germination and tetrazolium testing. Seed Sci. Tec. 15: 691-698.

R CORE TEAM. 2014. A language and environment for statistical computing. R Foundation for Statistical Computing, Vienna, Austria. URL http:/www.Rproject.org/

SOUTHGATE, B. J. 1979. Biology of Bruchidae. Ann. Rev. Entomol. 24: 449-473.

STEPHENSON, A. G. 1981. Flower and fruit abortion: Proximate causes and ultimate functions. Annu. Rev. Ecol. Syst. 12: 253-279.

STOKKEBO, S. \& I. C. W HARDY. 2000. The importance of being gravid: egg load and contest outcome in a parasitoid wasp. Anim. Behav. 59: 1111-1118.

SUTHERLAND, S. 1986. Patterns of fruit-set: what controls fruit-flower ratios in plants? Evolution 40: 117-128.

TAKAKURA, K. 2002. The specialist seed predator Bruchidius dorsalis (Coleoptera: Bruchidae) plays a crucial role in the seed germination of its host plant, Gleditsia japonica (Leguminosae). Funct. Ecol. 16: 252-257.

TOMAZ, C. A., D. KESTRING \& M. N. ROSSI. 2007. Effects of the seed predator Acanthoscelides schrankiae on viability of its host plant Mimosa bimucronata. Biol. Res. 40: 281-290.

VELEZ, S. 2013. Interacciones entre Prosopis, insectos y mamiferos: implicancias en la depredacion y supervivencia de las semillas. Doctoral Thesis. National University of Córdoba, Argentina.

ZAR, J. H. 1999. Biostatistical analysis. Pearson Education, India.

Recibido el 5 de junio de 2015, aceptado el 13 de julio de 2015 . 